Oksana Ruda

Narodowa Akademia Nauk Ukrainy

\title{
Polityka językowa Polski i Czechosłowacji wobec mniejszości ukraińskiej w okresie międzywojennym (na przykładzie szkolnictwa Galicji i Zakarpacia)
}

DOI: $10.19195 / 1643-0328.23 .10$

Słowa kluczowe: II Rzeczpospolita, Czechosłowacja, mniejszości narodowe, polityka językowa, szkolnictwo

\section{Wprowadzenie}

Podstawowym warunkiem rozwoju oświaty i kultury mniejszości narodowych jest realizacja postulatu nauczania $\mathrm{w}$ ich języku macierzystym. II Rzeczpospolita i Czechosłowacja zetknęły się ze skomplikowaną sytuacją językową na kontrolowanych przez nie etnicznych terenach ukraińskich — wschodniej części Galicji i Zakarpaciu. Władze państwowe Czechosłowacji oraz Polski w różnym stopniu realizowały zapotrzebowanie mniejszości ukraińskiej na oświatę w jej języku ojczystym.

Poniższy artykuł dotyczy polityki językowej międzywojennej Polski oraz analogicznych procesów w Czechosłowacji. Jego celem jest przedstawienie zakresu uprawnień językowych przyznanych Ukraińcom w szkolnictwie przez II Rzeczpospolitą i Czechosłowację. Podjęta analiza ma za zadanie ukazać podobieństwa i różnice prawne dotyczące języka ukraińskiego w obu państwach.

Przed przystąpieniem do szczegółowych rozważań należy zdefiniować pojęcie polityki językowej. Jest to ogół działań (politycznych, prawnych, administracyjnych) mających na celu regulowanie stosunków językowych w państwie. Termin ten ma kilka aspektów, obejmujących różne poziomy obecności języka w życiu publicznym i systemie edukacyjnym. Walery Pisarek słusznie zauważa, że aby opisać politykę językową, należy wziąć pod uwagę co najmniej trzy jej aspekty: prawny (obejmuje wszelkie regulacje ze strony państwa dotyczące języka i jego statusu), kulturalno-językowy (odnosi się do działań ukierunkowanych na poprawność językową) i edukacyjny (dotyczy działań w dziedzinie nauczania języków obcych $)^{1}$. Jednym z elementów polityki językowej jest ustawodawstwo

${ }^{1}$ Szerzej zob. W. Pisarek, Polityka językowa w wybranych krajach europejskich, [w:] Polska polityka językowa w Unii Europejskiej, red. J. Warchala, D. Krzyżyk, Katowice 2008, s. 79-105. 
językowe, którego elementami są ustawy językowe, wprowadzane w celu uregulowania statusu języka urzędowego oraz języków regionalnych i mniejszościowych używanych na danym terytorium. Kierunki polityki językowej prowadzonej przez II Rzeczpospolitą oraz przez Czechosłowację wyznaczało kilka czynników, wśród których należy wymienić przede wszystkim wielonarodowość, wielojęzyczność i wielowyznaniowość tych państw. Politykę w tym zakresie komplikowało zróżnicowanie terytorium obu państw ze względu na sytuację językową, niejednakowe roszczenia poszczególnych grup etnicznych i ich różny stosunek wobec państw polskiego i czechosłowackiego. Wymienione czynniki domagały się uwzględnienia w ustawodawstwie językowym. Dodatkowym problemem, zwłaszcza w Polsce, było nakładanie się odmienności narodowościowych i językowych z wyznaniowymi. Na językową politykę Polski wpłynęło także ograniczenie praw polszczyzny w dobie rozbiorów, które spowodowało konieczność podjęcia działań repolonizacyjnych. Reakcją na ograniczenie praw polszczyzny w dobie rozbiorów były decyzje zmierzające do rozszerzenia zakresu stosowania języka polskiego kosztem rosyjskiego, niemieckiego, a także ukraińskiego ${ }^{2}$.

Podstawą prawną wejścia terytorium współczesnego Zakarpacia w skład Czechosłowacji stały się uchwały paryskiej konferencji pokojowej (1919), traktat pokojowy podpisany w dniu 10 września 1919 r. w Saint-Germain-en-Laye oraz traktat z Trianon podpisany 4 czerwca $1920 \mathrm{r}$. Zapóźnione kulturowo, zacofane ekonomicznie terytorium weszło w skład Czechosłowacji pod oficjalną nazwą „Ruś Podkarpacka”. W okresie międzywojennym kraj ten zamieszkiwało blisko pół miliona Ukraińców (62,17\% ludności kraju). Za czasów węgierskich i czechosłowackich określano tę ludność mianem Rusinów i uważano za naród odrębny od Ukraińców, choć blisko z nimi spokrewniony ${ }^{3}$. Ruś Podkarpacka weszła w skład Czechosłowacji dobrowolnie, na zasadach federacyjnych, z perspektywą uzyskania szerokiej autonomii. Wobec ludności miejscowej Czechosłowacja prowadziła zróżnicowaną politykę, uzależnioną od sytuacji wewnętrznej oraz zewnętrznych uwarunkowań geopolitycznych ${ }^{4}$.

Galicja znalazła się w granicach państwa polskiego w wyniku przegranej przez Zachodnioukraińską Republikę Ludową wojny z Polską w latach 1918-1919. Decyzja Rady Ambasadorów z 15 marca 1923 r., przyznająca Polsce Galicję, była jedynie uznaniem przez państwa ententy już istniejącego stanu rzeczy. Jednocześnie jednak zobowiązywała ona państwo polskie do przyznania Galicji autonomii, a Ukraińców, którzy stanowili najliczniejszą poza Polakami grupę (około 16\%), zmuszała do rezygnacji z walki o budowę własnego niezależnego państwa i do przystosowania się do życia w nowych warunkach ${ }^{5}$. Ukraińcy galicyjscy, nie mogąc się pogodzić z polską dominacją na obszarze, który uważali za ukraiński (procent ludności ukraińskiej w Galicji w stosunku do ogółu wynosił

2 E. Woźniak, Polityka językowa państwa polskiego w okresie międzywojennym, „Socjolingwistyka” 29, 2015, s. 8-9, 11.

3 Tymczasem większość historyków ukraińskich uważa Rusinów za jedną z grup etnicznych wewnątrz narodu ukraińskiego.

4 Szerzej zob. A. Stec, Polityka Czechosłowacji wobec zagadnienia ukraińskiego w kontekście stosunków czechostowacko-polskich w latach 1918-1938, „Przegląd Geopolityczny” 8, 2014, s. 63-64.

5 M. Syrnyk, Ukraińcy w Polsce 1918-1939: oświata i szkolnictwo, Wrocław 1996, s. 29. 
w województwie stanisławowskim 72,9\%, tarnopolskim - 54,5\%, lwowskim - 44,6\%), długo jeszcze nie uznawali polskiej państwowości (bojkotowali powszechny spis ludności w 1921 r., wybory do sejmu i senatu w 1922 r., rozwijali także tajną działalność o charakterze wojskowym $)^{6}$.

\section{Międzynarodowe zobowiązania w dziedzinie uprawnień językowych}

W dużym stopniu polityka językowa państw w okresie międzywojennym zdeterminowana była międzynarodowymi zobowiązaniami. Mały traktat wersalski podpisany przez Polskę 28 czerwca 1919 r. zobowiązywał ją do uznania postanowień zawartych w art. 2-8 za prawa zasadnicze ${ }^{7}$. Dotyczyły one zabezpieczenia praw mniejszości w zakresie nabywania obywatelstwa, uprawnień językowych, swobody praktyk religijnych oraz zakładania i prowadzenia na własny koszt instytucji dobroczynnych, szkół i innych zakładów wychowawczych, z prawem używania w nich własnego języka. Powyższe przepisy miały zapewnić mniejszościom prawo do autonomii kulturalnej ${ }^{8}$. Ze względu na postanowienia zawarte w traktacie (art. 9) w miastach i okręgach zamieszkanych przez znaczny odłam obywateli posługujących się językiem innym niż polski rząd, na podstawie odpowiednich rozporządzeń, powinien zapewnić uzyskanie edukacji początkowej w języku ojczystym z obowiązkowym nauczaniem języka polskiego. Takie szkoły podstawowe miały funkcjonować $\mathrm{z}$ udziałem środków pochodzących $\mathrm{z}$ budżetu. Umowa nie przewidywała natomiast zapewnienia mniejszościom uzyskania wykształcenia średniego i wyższego w języku ojczystym. Należy nadmienić, iż postanowienia art. 9 zostały tylko częściowo zrealizowane w przepisach ustawodawczych i rządowych ${ }^{9}$. W roku 1934 państwo polskie oficjalnie odwołało swój podpis pod małym traktatem wersalskim.

W pewnym stopniu obrony praw językowych mniejszości narodowych w dziedzinie oświaty dotyczył również traktat pokojowy między Polską, Rosją i Ukrainą, podpisany w Rydze 18 marca 1921 r. Na mocy art. 7 Ukraińcy, podobnie jak Rosjanie i Białorusini, uzyskali, w ramach ustawodawstwa wewnętrznego, prawo do pielęgnowania swojego języka ojczystego, organizowania i popierania własnego szkolnictwa, rozwijania swojej kultury. Powyższy artykuł miał jednak charakter deklaracji i nie przewidywał żadnych gwarancji w zakresie zapewnienia praw językowych tym narodom.

${ }^{6}$ A. Świątek, Polacy i Ukraińcy: W II Rzeczpospolitej. Narastający antagonizm, http://nowahistoria.interia.pl/ii-rzeczpospolita/news-polacy-i-ukraincy-w-ii-rzeczpospolitej-narastajacy-antagoniz,nId,1537186 (dostęp: 23 lutego 2017).

7 Traktat między Głównymi Mocarstwami Sprzymierzonymi i Stowarzyszonymi a Polską, podpisany w Wersalu dnia 28 czerwca 1919 r., Dz.U. z 1920 r. Nr 110, poz. 728.

8 J. Ogonowski, Uprawnienia językowe mniejszości narodowych w Rzeczypospolitej Polskiej 1918-1939, Warszawa 2000, s. 44; В. Марковський, Міжнародно-правові зобов'язання Другої Речі Посполитої щодо української національної меншини у сфері мовних відносин, „Вісник Львівського університету. Серія юридична" 2013, nr 57, s. 108.

9 J. Ogonowski, op. cit., s. 48. 
Prawa mniejszości narodowych państwa czechosłowackiego ustanowiono w traktacie pokojowym podpisanym przez Czechosłowację w 1919 r. I tak art.1-8 rozdziału I traktatu były w pełni zgodne z odpowiednimi artykułami Małego traktatu wersalskiego podpisanego z Polską. Prawa językowe mniejszości narodowych, podobnie jak w polskiej wersji dokumentu, zostały omówione w postanowieniach art. 7-9. Warto zauważyć, że treść art. 9 traktatu znacząco się różniła od odpowiedniego artykułu traktatu pokojowego podpisanego z Polską. Tak więc omówiony artykuł deklarował, iż odpowiednie ustawy powinny zapewnić wszystkim obywatelom państwa możliwość kształcenia swoich dzieci w języku ojczystym w szkołach różnego poziomu — od szkół podstawowych do uczelni wyższych ${ }^{10}$.

Zobowiązania Czechosłowacji w zakresie nadania Rusi Podkarpackiej szerokiej autonomii z własnym samorządem były zamieszczone w art. 10-13 rozdziału II traktatu ${ }^{11}$. Realia jednak odstawały od tych zapisów. Agnieszka Stec słusznie zauważa, że opierając się na słabo rozwiniętym poczuciu tożsamości narodowej ukraińskiej ludności miejscowej, władze Czechosłowacji postanowiły najpierw wzmocnić jej lojalność i przywiązanie do państwa (przez popieranie poczucia odrębności kulturowo-językowej Rusinów, rozwój gospodarczy, społeczny i kulturowy kraju), a następnie rozpocząć powoli wdrażanie polityki asymilacyjnej ${ }^{12}$. Ruś Podkarpacka miała stać się kolejną prowincją Czechosłowacji. Aczkolwiek do jesieni 1938 r. władze nie wywiązały się swoich zobowiązań dotyczących autonomii ${ }^{13}$.

\section{Charakterystyka ustawodawstwa językowego w szkolnictwie}

Prawa językowe mniejszości narodowych w szkolnictwie regulowały również ustawy i rozporządzenia wewnętrzne Polski i Czechosłowacji. I tak w Polsce art. 109 konstytucji z 17 marca 1921 r. gwarantował mniejszościom prawo do zachowania własnej narodowości, rozwoju języka ojczystego i tożsamości narodowej. Na mocy art. 110 ustanowiono prawo mniejszości narodowych i religijnych do powoływania i utrzymywania placówek oświatowych, a także do swobodnego posługiwania się w ramach takich placówek językiem ojczystym ${ }^{14}$. Ustawa konstytucyjna z 23 kwietnia 1935 r. inaczej traktowała prawa i wolności obywatelskie. Jak podkreślają Henryk Chałupczak i Tomasz Browarek, konstytucja kwietniowa stała na stanowisku podporządkowania jednostki interesom zbiorowości reprezentowanym przez państwo, prawom wolnościowym nadała zaś cha-

10 С. Черничко, Ч. Фединець, Наш місиевий Вавилон: Історія мовної політики на території сучасного Закарпаття у першій половині ХХ століття (до 1944 року): Монограбія, Ужгород 2014, s. 67-68; J. Ogonowski, op. cit., s. 257-258.

11 Ю. Шевельов, Українська мова в першій половині двадиятого століття (1900-1941). Стан i cmamyc, Київ 1987, s. 240-241.

12 A. Stec, op. cit., s. 66-67.

13 M. Jarnecki, Między centralizmem a autonomia. Administracja czechosłowacka na Rusi Zakarpackiej (1918-1938), „Dzieje Najnowsze” 37, 2005, nr 3, s. 9.

14 Ustawa z dnia 17 marca 1921 r. - Konstytucja Rzeczypospolitej Polskiej, Dz.U. z 1921 r. Nr 44, poz. 267. 
rakter ogólny, uznając za ich granicę wieloznaczne „dobro powszechne”. Przenosiła ona z konstytucji marcowej większość praw dotyczących mniejszości narodowych (zwłaszcza art. 109-110 ${ }^{15}$. Jednak ustawy konstytucyjne nie gwarantowały mniejszościom prawa do pobierania nauki w języku ojczystym w szkołach średnich i wyższych. W zasadzie powtórzyły one tylko za umowami międzynarodowymi ogólne sformułowania dotyczące praw językowych obywateli polskich innych narodowości ${ }^{16}$.

Konstytucja Czechosłowacji z 29 lutego 1920 r. gwarantowała mniejszościom narodowym znacznie szersze prawa językowe. Treść $\$ 128,130-132$ prawie w całości była zgodna z treścią art. 7-9 traktatu pokojowego z roku 1919. Postanowienia $\$ 131$ przewidywały, iż w miastach i okręgach zamieszkanych przez dużą liczbę czechosłowackich obywateli mówiących językiem innym niż czechosłowacki ${ }^{17}$ ich dzieciom $\mathrm{w}$ ramach edukacji publicznej gwarantuje się możliwość pobierania nauki w języku ojczystym zgodnie $\mathrm{z}$ odpowiednimi zasadami ogólnymi ${ }^{18}$. Równocześnie uczniowie mieli uczyć się języka czechosłowackiego jako przedmiotu obowiązkowego. Wymuszonej asymilacji mniejszości narodowych zabraniał $\$ 134^{19}$.

Istotną z punktu widzenia utworzenia mechanizmu gwarantującego mniejszościom swobodny rozwój stała się ustawa z dnia 29 lutego 1920 r. wydana na podstawie art. 129 konstytucji dotycząca zasad prawa językowego w Czechosłowacji. Zgodnie z $\$ 1$ językiem państwowym i oficjalnym w państwie stał się język czechosłowacki. Prawa językowe mniejszości gwarantował $\$ 2$ ustawy. Jego postanowienia przewidywały utworzenie jednostki administracyjno-terytorialnej, w obrębie której praw językowych nabywała ta mniejszość narodowa, która zgodnie z wynikami spisu ludności stanowiła tutaj nie mniej niż 20\% ogółu ludności. Prawo mniejszości do pobierania nauki w języku ojczystym gwarantował $₫ 5$ ustawy ${ }^{20}$.

Prawa języka rusińskiego na Rusi Podkarpackiej określał $\$ 6$ ustawy, który przewidywał, iż powołany w przyszłości parlament będzie mógł samodzielnie uchwalać ustawy językowe. Do chwili uregulowania omówionej kwestii obowiązywała czynna ustawa językowa, z uwzględnieniem jednak szczególnych stosunków językowych w kraju ${ }^{21}$.

15 Ustawa konstytucyjna z dnia 23 kwietnia 1935 r., Dz.U. z 1935 r. Nr 30, poz. 227; H. Chałupczak, T. Browarek, Mniejszości narodowe w Polsce: 1918-1995, Lublin 1998, s. 44.

${ }^{16}$ E. Woźniak, op. cit., s. 17-18.

17 Uznanie czechosłowackiego języka za państwowy było przejawem „czechosłowakizmu” — oficjalnej ideologii Republiki Czechosłowackiej, według której Słowacy i Czesi należą do jednego narodu czechosłowackiego.

18 Ю. Шевельов, op. cit., s. 241; J. Kaplanová, Ústavněprávní ochrana menšin, Olomouc 2011, s. 17, http://docplayer.cz/38956882-Ustavnepravni-ochrana-mensin.html (dostęp: 20 października 2017).

19 The Law of February $29^{\text {th }} 1920$ whereby the Constitutional Charter of the Czechoslovak Republic is introduced, [w:] The Constitution of the Czechoslovak Republic, wstęp J. Hoetzl, V. Joachim, Prague 1920, s. 45-46; J. Ogonowski, op. cit., s. 258-259.

20 An Act Dated the $29^{\text {th }}$ of February 1920 in Pursuance of $\$ 129$ of the Constitutional Charter Establishing the Principles of Language Rights within the Czechoslovak Republic, [w:] The Constitution of the Czechoslovak Republic..., s. 47-50; С. Черничко, Ч. Фединець, op. cit., s. 72-74.

${ }^{21}$ R. Petráš, Menšiny v meziválečném Československu. Právní postavení národnostních menšin v první Československé republice a jejich mezinárodně právní ochrana, Praha 2009, s. 317. 
W rzeczywistości do końca lat 30. XX w. parlament nie został zwołany. Warto zauważyć, że na Rusi Podkarpackiej funkcjonowały trzy języki - ukraiński, rosyjski oraz rusiński, który sprowadzał się do nadania formy literackiej zakarpackim dialektom języka ukraińskiego ${ }^{22}$. W tym względzie należy przypomnieć, że Rusini byli głównie ludnością wiejską bez wyraźnie skrystalizowanej tożsamości narodowej. Dlatego właśnie krzyżowały się tu najrozmaitsze trendy polityczne i kulturowe (moskwofilstwo (rusofilstwo) ${ }^{23}$, ukrainofilstwo, rusinofilstwo). Sytuacja ta powodowała zamęt, zwłaszcza w kwestii języka szkolnictwa miejscowego ${ }^{24}$.

Rozporządzenie rządowe z dnia 3 lutego 1926 r. powtarzało treść ustawy z 1920 r., a dodatkowo przewidywało możliwość złożenia dokumentów i wniosków w języku rusińskim lub małorosyjskim (ukraińskim) do wszystkich sądów i instytucji regionu. W tym języku, oraz w czechosłowackim, należało pisać nazwy instytucji i zamieszczać oficjalne ogłoszenia. Ustawy językowe i rozporządzenia nadawały mniejszościom narodowym stosunkowo szerokie prawa językowe w szkolnictwie. Co istotne, państwo czechosłowackie ustawami językowymi zobowiązywało mniejszości do używania języka w tych regionach, gdzie udział obcojęzycznych obywateli osiągał określony poziom procentowy. W ten sposób na terytorium współczesnego Zakarpacia władze czechosłowackie umożliwiły korzystanie z języka rusińskiego na poziomie oficjalnym, w szczególności w szkolnictwie, nie zważając na to, że autonomia nigdy nie została zrealizowana w praktyce ${ }^{25}$.

Jedną z największych trudności w kwestii językowej był na Rusi Podkarpackiej brak języka literackiego, którym można byłoby posługiwać się do celów edukacyjnych. Termin ,język narodowy”, który od 1919 r. stosowano w dokumentach oficjalnych, nie był sprecyzowany i nie było wiadomo, o jaki język chodzi. Biorąc pod uwagę rekomendacje specjalistów Ministerstwa Szkolnictwa i Edukacji Narodowej, rozpoczęto wprowadzanie języka ukraińskiego z pisownią etymologiczną, której od dłuższego czasu już nie stosowano i utrwalała ona archaiczne formy języka ukraińskiego. Zarówno ukrainofile, jak i moskwofile poddawali krytyce czechosłowacką politykę językową. Sytuację językową znacznie komplikowały naruszenia podstawowych zasad nauczania języków mniejszości narodowych w szkole, zwłaszcza korzystanie w szkołach z podręczników rosyjskojęzycznych, które nie zostały zatwierdzone przez Ministerstwo Szkolnictwa i Edukacji Narodowej. Zdarzało się, że w ramach jednej szkoły nauczyciele uczyli dzieci, używając różnych języków ${ }^{26}$. Warto zauważyć, że w 1938 r. na Zakarpaciu istniało 809 szkół pod-

22 А. Берегсасі, С. Черничко, Державний статус украӥнської/русинської (руської) мови на Закарnammi у XX столітmi, [w:] Teka Komisji Polsko-Ukraińskich Związków Kulturowych, Nr 7, Lublin 2012, s. 30 .

23 Moskwofilstwo, moskalofilstwo lub rusofilstwo — językowo-literacki i społeczno-polityczny prąd istniejący wśród ukraińskiej ludności Galicji, Bukowiny i Rusi Podkarpackiej od połowy XIX w. do lat 30. XX w. Głosił wspólnotę narodowo-kulturową, następnie również państwową i polityczną z narodem rosyjskim.

24 A. Stec, op. cit., s. 65-66.

25 С. Черничко, Ч. Фединець, ор. cit., s. 75-77.

26 В. Ганчин, Деякі історично-правові аспекти мовного питання в Закарпатті, [w:] Українська мова на Закарпатті у минулому і сьогодні. Матеріали науково-практичної конференції (Ужгород, 
stawowych, w tym 469 z ukraińskim językiem wykładowym. Ponadto istniały wtedy 4 gimnazja ukraińskie i 3 ukraińskie seminaria nauczycielskie.

Na początku lat 20. XX w. w szkołach i instytucjach państwowych pozwolono posługiwać się językiem ukraińskim, rosyjskim oraz rusińskim na jednakowych zasadach, z kolei wybór języka komunikacji pozostawał w gestii samych obywateli. Pod koniec lat 20. i w ciągu lat 30. rządowa polityka językowa uległa zmianie w kierunku czechizacji i poparcia dla tendencji moskwofilskich ${ }^{27}$. W czerwcu 1930 r. władze lokalne Rusi Podkarpackiej zobowiązały inspektorów szkolnych do posługiwania się w korespondencji oficjalnej językiem czechosłowackim, uzasadniając taką decyzję nierozstrzygniętą kwestią językową w kraju. Niemniej jednak pod presją protestów masowych w sierpniu tegoż roku nakaz został unieważniony. Natomiast już w listopadzie 1930 r. Ministerstwo Szkolnictwa i Edukacji Narodowej pozwoliło na korzystanie w szkołach z podręczników rosyjskich, a w październiku 1936 r. rekomendowało je do stosowania w szkołach. Ostatecznie w 1937 r. doszło do zrównania praw języka ukraińskiego i rosyjskiego. Należy nadmienić, że użycie przymiotnika „ukraiński” było zabronione jeszcze w roku 1933 i powtórnie w $1936^{28}$. W latach 30 . XX w. władze czechosłowackie stopniowo wycofywały się z pomocy finansowej udzielanej ukraińskim instytucjom i stowarzyszeniom kulturalno-oświatowym, co doprowadziło do ograniczenia ich działalności. Stało się to m.in. główną przyczyną upadku Instytutu Pedagogicznego im. M. Drahomanowa (1933) i Ukraińskiej Akademii Gospodarczej w Poděbradach $(1935)^{29}$. Młodzież ukraińska mogła studiować jedynie na Wolnym Uniwersytecie Ukraińskim w Pradze, który od 1921 r. był finansowany przez rząd czechosłowacki. Język ukraiński otrzymał status języka oficjalnego dopiero 25 listopada 1938 r. po nadaniu przez II Republikę Czechosłowacką Zakarpaciu statusu autonomii w dniu 22 listopada 1938 r. Językiem państwowym na Zakarpaciu język ukraiński stał się po ogłoszeniu niepodległości w dniu 14 marca 1939 r.

W Galicji władze polskie prowadziły odmienną politykę narodową i językową, ukierunkowaną na asymilację miejscowej ludności ukraińskiej. Warto zauważyć, że w żadnym innym regionie Polski oprócz wschodniej części Galicji język polski nie miał konkurenta mogącego zagrozić jego pozycji lub choćby ją ograniczyć. Natomiast w Galicji język polski miał uporczywego przeciwnika w postaci języka ukraińskiego. Przeciwstawianie się nowej randze języka polskiego traktowali Ukraińcy jako ważne ogniwo walki z państwowością polską, którą, przegrawszy zbrojnie, próbowali kontynuować politycznie ${ }^{30}$.

Jednym z pierwszych programów dotyczących polityki Polski wobec Ukraińców był program premiera Władysława Sikorskiego składający się z dwóch dokumentów, czyli odezwy do obywateli Kresów Wschodnich oraz tajnego opracowania w sprawie zaleceń polityki rządu na Kresach, wydanych w marcu i kwietniu 1923 r. Owe dokumenty zakła-

5-6 травня 1992 року), red. Б. Галас, В. Гадорець, В. Задорожний, Ужгород 1993, s. 25-26; Ю. Шевельов, op. cit., s. 243.

27 K. Mozgawa, Ruś Zakarpacka w polityce czechosłowackiej (1920-1938), „Koło Historii” 2015, nr 16, s. 103.

28 Ю. Шевельов, ор. cit., s. 249.

29 A. Stec, op. cit., s. 74.

30 J. Ogonowski, op. cit., s. 53, 59. 
dały normalizację stosunków polsko-ukraińskich poprzez zjednoczenie na stałe terenów południowo-wschodnich $\mathrm{z}$ państwem polskim, co w efekcie miało doprowadzić do asymilacji Ukraińców ${ }^{31}$. Jednak $\mathrm{w}$ tych dokumentach nie wspomniano o nadaniu autonomii Galicji. Poruszono m.in. kwestię szkolnictwa. Zasygnalizowano, że rozwój szkolnictwa w języku innym niż polski nie może odbywać się ze szkodą dla szkoły polskiej ${ }^{32}$. Do umocnienia państwowości polskiej na terenach południowo-wschodnich zmierzał również rząd Władysława Grabskiego. Ważnym krokiem w kwestii regulacji prawnych tych terenów były projekty tzw. ustaw kresowych zaproponowanych przez rząd. Projekt ustaw został uchwalony przez sejm w lipcu 1924 r. Owe ustawy dotyczyły języka państwowego i języków władz rządowych oraz samorządowych w aparatach administracyjnym, sądowym, prokuratorskim, notarialnym oraz w organizacji edukacji. Według Mateusza Kępy podstawowe założenia ustaw jawiły się następująco: język polski jako podstawowy język państwowy, języki mniejszości pełniły tylko funkcje pomocnicze, zmieniono nazwę „ukraiński” i wprowadzono prawnie ustanowioną nazwę „ruski”. Kępa słusznie zauważa, że w tych ustawach ludność ukraińska została pozbawiona przymiotów własnej kultury, a wręcz własnej nazwy. Działalność prawodawcza rządu Grabskiego zmierzała do usunięcia „sprawy ukraińskiej” i nadania jej specyfiki sprawy „ruskiej”, a także miała na celu polonizację ludności ukraińskiej ${ }^{33}$.

Próbą uregulowania kwestii językowej w szkolnictwie stało się uchwalenie ustawy z dnia 31 lipca 1924 r. zawierającej niektóre postanowienia o organizacji szkolnictwa. Została ona uzupełniona przez rozporządzenie Ministra Wyznań Religijnych i Oświecenia Publicznego z dnia 7 stycznia 1925 r. w sprawie wykonania ustawy z dnia 31 lipca 1924 r., dotyczyła bowiem województw południowo-wschodnich. Karol Sanojca słusznie zauważa, że to terytorialne ograniczenie zasięgu obowiązywania ustawy było jedną ze słabości przyjętych rozwiązań. Wyłączono z niej Chełmszczyznę i Podlasie, gdzie mieszkało ponad 200 tys. Ukraińców. Brak możliwości utworzenia na tych terenach państwowych szkół ukraińskich (czy choćby utrakwistycznych) spotykał się z ostrą krytyką ukraińskiej ludności ${ }^{34}$.

Powyższa ustawa miała zapewnić warunki do wspólnego nauczania i wychowywania dzieci różnego pochodzenia etnicznego zamieszkujących w województwach południowo-wschodnich. Typem podstawowym szkoły państwowej miała stać się szkoła utrakwistyczna (art. 2). Szkoły prywatne mniejszości narodowych miały być powoływane na tych samych warunkach, co szkoły polskie (art. 1). Nauczanie w języku mniejszości narodowej było możliwe, pod warunkiem że przedstawiciele mniejszości stanowią na określonym terenie nie mniej niż 25\% ludności, a rodzice nie mniej niż 40 uczniów złożyli w tej sprawie odpowiednie wnioski. Jeżeli natomiast szkoła liczyła 20 uczniów będących Polakami,

31 M. Kępa, Polityka narodowościowa II Rzeczypospolitej wobec Łemków, „Wrocławskie Studia Politologiczne" 20, 2016, s. 56; A. Świątek, op. cit;; A. Chojnowski, Koncepcje polityki narodowościowej rządów polskich w latach 1921-1939, Wrocław 1979, s. 21.

32 M. Syrnyk, op. cit., s. 34-35.

${ }^{33}$ M. Kępa, op. cit., s. 57-58.

${ }^{34}$ K. Sanojca, Relacje polsko-ukrainskie w szkolnictwie państwowym południowo-wschodnich województw Drugiej Rzeczypospolitej, Kraków 2013, s. 33. 
stawała się dwujęzyczna: już od pierwszej klasy wprowadzano naukę czytania i pisania w języku polskim, z kolei w języku ukraińskim wykładano tylko nauki przyrodnicze, rysowanie, prace ręczne i wychowanie fizyczne. Zgodnie $\mathrm{z}$ treścią art. 4 ustawy uczniowie wszystkich państwowych i prywatnych szkół obejmujących klasy 1-3 z niepolskim językiem nauczania obowiązkowo uczyli się języka państwowego. Artykuł zobowiązywał ponadto szkoły obejmujące klasy 4-7 do prowadzenia po polsku nauki historii Polski i nauki o Polsce współczesnej ${ }^{35}$. Utrakwizm do szkolnictwa średniego włącznie z państwowymi seminariami nauczycielskimi wprowadzały art. 5 i 6 ustawy szkolnej.

Polskie ustawodawstwo językowe w zakresie szkolnictwa było oceniane przez mniejszości skrajnie krytycznie. Najwięcej zastrzeżeń i kontrowersji budził program utrakwizacji szkolnictwa. Dla Ukraińców szkoła wspólna z polską oznaczała utratę dotychczasowego dorobku (zwłaszcza z czasów austriackich). Za krzywdzące uważano także ograniczenie funkcjonowania ustawy do gmin, w których liczba mieszkańców narodowości ukraińskiej przekraczała 25\%, przez co część Ukraińców pozbawiono prawa do decydowania o języku szkoły. Obawiano się również nadużyć w trakcie składania deklaracji szkolnych. Starając się wywierać nacisk na władze polskie za pośrednictwem instytucji międzynarodowych, Ukraińcy kierowali obszerne memoriały do Ligi Narodów, twierdząc, że obowiązujące w Polsce ustawy szkolne są niezgodne z postanowieniami traktatu o ochronie mniejszości ${ }^{36}$.

Powołanie średnich szkół z ukraińskim językiem nauczania było możliwe tylko w przypadku wysunięcia takiego żądania przez rodziców 150 uczniów uczęszczających do szkół polskojęzycznych odpowiedniego typu w jednym powiecie czy mieście. Aby nauczanie w szkołach fachowych prowadzone było w dwóch językach — w języku państwowym i języku mniejszości narodowej - uczniowie narodowości niepolskich musieli stanowić 40\% wszystkich uczniów szkoły. Zgodnie z ustawą język nauczania miał zostać ustalony na podstawie wyników plebiscytów szkolnych ${ }^{37}$. W skutek plebiscytów liczba szkół ukraińskich spadła z 2555 w 1922 r. do 455 w 1938 r. Ponadto istniały wtedy 3064 szkoły dwujęzyczne i 2123 szkoły z polskim językiem nauczania, w których prowadzona była nauka języka ukraińskiego jako przedmiotu. W Okręgu Szkolnym Lwowskim szkoły z ukraińskim językiem wykładowym stanowiły w roku szkolnym 1921/22 około 51,7\% ogólnej liczby szkół. Natomiast w roku szkolnym 1937/38 zaledwie 6,9\% i obejmowały niecałe 5\% uczniów narodowości ukraińskiej. Ponadto istniało wtedy 6 gimnazjów ukraińskich, w tym 2 utrakwistyczne ${ }^{38}$.

Po przewrocie majowym 1926 r. zapowiedziano rewizję ustawy szkolnej z 1924 r. i zniesienie plebiscytów szkolnych. Stwierdzono, iż asymilacja narodowa jest rzeczą niemożliwą. Naczelnym celem państwa miała być asymilacja państwowa mniejszości narodowych - afirmacja instytucji państwa i odpowiedzialność za losy kraju wszystkich zamieszkujących Polskę obywateli, bez względu na ich przynależność narodową. Mniej-

35 Ustawa $\mathrm{z}$ dnia 31 lipca 1924 r. zawierająca niektóre postanowienia o organizacji szkolnictwa, Dz.U. z 1924 r. Nr 79, poz. 766.

36 K. Sanojca, op. cit., s. 34-35, 52.

37 H. Chałupczak, T. Browarek, op. cit., s. 46.

38 M. Syrnyk, op. cit., s. 54-55. 
szościom miano zapewnić warunki do swobodnego pielęgnowania kultury narodowej. W istocie stosunek rządów sanacyjnych do systemu oświaty dla mniejszości narodowych sprowadzał się do uznania supremacji języka państwowego ${ }^{39}$. Potwierdzają tę tezę także ustawy jędrzejewiczowskie z 11 marca 1932 r. o ustroju szkolnym i o prywatnych szkołach oraz zakładach naukowych i wychowawczych. W systemie szkolnictwa mniejszościowego ustawy te preferowały, kosztem placówek oświatowych z językiem wykładowym mniejszości, lekcje języka danej mniejszości jako przedmiotu oraz zwiększały nadzór państwa nad całym szkolnictwem. Do 1932 r. w Galicji istniało 8 seminariów utrakwistycznych, kursy koedukacyjne $\mathrm{z}$ wykładowym językiem ukraińskim we Lwowie i utrakwistyczne w Zaleszczykach oraz 7 prywatnych seminariów nauczycielskich z ukraińskim językiem wykładowym. Wszystkie te placówki kształciły nauczycieli na potrzeby szkolnictwa ukraińskiego. Wraz z wejściem w życie ustawy z 1932 r. szkoły tego typu upadły. Kształcenie nauczycieli przejęły nowe licea pedagogiczne i pedagogie, w których językiem wykładowym był język polski ${ }^{40}$.

Jedyną ukraińską wyższą uczelnią w państwie polskim była działająca od roku 1929 Akademia Teologiczna we Lwowie. W tej uczelni mogli studiować jedynie duchowni. W 1919 r. wszystkie ukraińskie katedry na Uniwersytecie Lwowskim zostały rozwiązane przez władze polskie. Ustawa z dnia 13 lipca 1920 r. o szkołach akademickich ustaliła zasadę, że językiem wykładowym szkół tego typu jest język polski (art. 9). „O tym, czy niektóre przedmioty mogą być wyjątkowo wykładane w innym języku, rozstrzyga senat szkoły"41. Natomiast art. 3 ustawy z dnia 15 marca 1933 r. o szkołach akademickich przewidywał, iż „językiem urzędowym i wykładowym szkół akademickich jest język polski; wyjątki od tej zasady wprowadzić może tylko ustawa" ${ }^{32}$. $Z$ tego właśnie powodu młodzież ukraińska miała trudności ze zdobyciem wykształcenia wyższego w języku ojczystym ${ }^{43}$.

Zestaw celów i zasad, którymi miała się kierować polska polityka oświatowa oraz językowa na terenach południowo-wschodnich, sformułowano pod koniec lat 30. Karol Sanojca zauważa, że zadaniem nadrzędnym miało być wychowanie młodzieży ukraińskiej w duchu obywatelskim, a przede wszystkim w akceptacji politycznego stanu rzeczy. Oznaczało to w praktyce utrzymanie szkół z ukraińskim językiem nauczania na obszarach zamieszkanych wyłącznie przez ludność ukraińską. W miejscowościach z ludnością mieszaną, gdzie działała szkoła z polskim językiem nauczania, postulowano tworzenie dla młodzieży ukraińskiej nie osobnych szkół, lecz oddziałów równoległych. Podstawowym typem placówki oświatowej na terenach południowo-wschodnich powinna być jednak szkoła polska - główny czynnik krzewienia polskiej kultury i umacniania państwowości. Realizacja rządowych pomysłów na uporządkowanie spraw oświatowych na terenach południowo-wschodnich została jednak wstrzymana wybuchem II wojny światowej $^{44}$.

\footnotetext{
39 K. Sanojca, op. cit., s. 43, 45.

40 H. Chałupczak, T. Browarek, op. cit., s. 70-71.

41 Ustawa z dnia 13 lipca 1920 r. o szkołach akademickich, Dz.U. z 1920 r. Nr 72, poz. 494.

42 Ustawa z dnia 15 marca 1933 r. o szkołach akademickich, Dz.U. z 1933 r. Nr 29, poz. 247.

43 H. Chałupczak, T. Browarek, op. cit., s. 72.

${ }^{44}$ K. Sanojca, op. cit., s. 60-61.
} 


\section{Podsumowanie}

Polska i Czechosłowacja prowadziły wobec mniejszości ukraińskiej Galicji i Zakarpacia odmienną politykę językową. Ustawodawstwo czechosłowackie dawało Ukraińcom stosunkowo szeroką możliwość korzystania z języka ojczystego w szkolnictwie. Mniejszości narodowe otrzymały możliwość pobierania nauki w szkołach podstawowych, średnich i wyższych w ich języku macierzystym. Na terenie współczesnego Zakarpacia funkcjonowały trzy języki: ukraiński, rosyjski i rusiński. Czechosłowackie ustawodawstwo językowe mieściło się w dwóch podstawowych aktach prawnych - ustawie językowej z dnia 29 lutego 1920 r. i rozporządzeniu egzekucyjnym z dnia 3 lutego 1926 r. Natomiast polskie ustawodawstwo językowe było rozproszone, co jest bezpośrednio związane z polityką narodową tego państwa. Polityka językowa Polski w szkolnictwie doprowadziła do zmniejszenia liczby szkół podstawowych z ukraińskim językiem nauczania i utrudnienia kształcenia się młodzieży ukraińskiej w szkołach wyższych. Władze czechosłowackie, szczególnie w latach 20. XX w., usiłowały podnieść poziom edukacji i kultury Ukraińców poprzez sprzyjanie zakładaniu ukraińskojęzycznych podstawowych, średnich i wyższych placówek oświatowych. Od lat 30. czechosłowacka polityka językowa uległa zmianie w kierunku czechizacji. Władze czechosłowackie stopniowo wycofały się z zakresu udzielanej pomocy finansowej dla ukraińskich szkół wyższych, co prowadziło do ograniczenia ich działalności.

\section{Bibliografia}

An Act Dated the $29^{\text {th }}$ of February 1920 in Pursuance of $\$ 129$ of the Constitutional Charter Establishing the Principles of Language Rights within the Czechoslovak Republic, [w:] The Constitution of the Czechoslovak Republic, wstęp J. Hoetzl, V. Joachim, Édition de la Société l'effort de la Tchécoslovaquie, Prague 1920.

Chałupczak H., Browarek T., Mniejszości narodowe w Polsce: 1918-1995, Wydawnictwo Uniwersytetu Marii Curie-Skłodowskiej, Lublin 1998.

Chojnowski A., Koncepcje polityki narodowościowej rząów polskich w latach 1921-1939, Zakład Narodowy im. Ossolińskich, Wydawnictwo Polskiej Akademii Nauk, Wrocław 1979.

Jarnecki M., Między centralizmem a autonomią. Administracja czechosłowacka na Rusi Zakarpackiej (19181938), „Dzieje Najnowsze” 37, 2005, nr 3.

Kaplanová J., Ústavněprávní ochrana menšin, Olomouc 2011, s. 17, http://docplayer.cz/38956882-Ustavnepravni-ochrana-mensin.html (dostęp: 20 października 2017)

Kępa M., Polityka narodowościowa II Rzeczypospolitej wobec Łemków, „Wrocławskie Studia Politologiczne" 20, 2016.

The Law of February $29^{\text {th }} 1920$ whereby the Constitutional Charter of the Czechoslovak Republic is introduced, [w:] The Constitution of the Czechoslovak Republic, wstęp J. Hoetzl, V. Joachim, Édition de la Société l'effort de la Tchécoslovaquie, Prague 1920.

Mozgawa K., Ruś Zakarpacka w polityce czechosłowackiej (1920-1938), „Koło Historii” 2015, nr 16.

Ogonowski J., Uprawnienia językowe mniejszości narodowych w Rzeczypospolitej Polskiej 1918-1939, Wydawnictwo Sejmowe, Warszawa 2000.

Petráš R., Menšiny v meziválečném Československu. Právní postavení národnostních menšin v první Československé republice a jejich mezinárodně právní ochrana, Karolinum, Praha 2009. 
Pisarek W., Polityka językowa w wybranych krajach europejskich, [w:] Polska polityka językowa w Unii Europejskiej, red. J. Warchala, D. Krzyżyk, Wydawnictwo Uniwersytetu Śląskiego, Katowice 2008.

Sanojca K., Relacje polsko-ukraińskie w szkolnictwie państwowym południowo-wschodnich województw Drugiej Rzeczypospolitej, Historia Iagellonica, Kraków 2013.

Stec A., Polityka Czechosłowacji wobec zagadnienia ukraińskiego w kontekście stosunków czechosłowacko-polskich w latach 1918-1938, „Przegląd Geopolityczny” 8, 2014.

Syrnyk M., Ukraińcy w Polsce 1918-1939: oświata i szkolnictwo, Krynica Design Studio, Wrocław 1996.

Świątek A., Polacy i Ukraińcy: W II Rzeczpospolitej. Narastający antagonizm, http://nowahistoria.interia. $\mathrm{pl} /$ ii-rzeczpospolita/news-polacy-i-ukraincy-w-ii-rzeczpospolitej-narastajacy-antagoniz,nId,1537186 (dostęp: 23 lutego 2017).

Traktat między Głównymi Mocarstwami Sprzymierzonymi i Stowarzyszonymi a Polską, podpisany w Wersalu dnia 28 czerwca 1919 r., Dz.U. z 1920 r. Nr 110, poz. 728.

Ustawa Konstytucyjna z dnia 23 kwietnia 1935 r., Dz.U. z 1935 r. Nr 30, poz. 227.

Ustawa z dnia 13 lipca 1920 r. o szkołach akademickich, Dz.U. z 1920 r. Nr 72, poz. 494.

Ustawa z dnia 17 marca 1921 r. — Konstytucja Rzeczypospolitej Polskiej, Dz.U. z 1921 r. Nr 44, poz. 267.

Ustawa z dnia 31 lipca 1924 r. zawierająca niektóre postanowienia o organizacji szkolnictwa, Dz.U. z 1924 r. $\mathrm{Nr} 79$, poz. 766.

Ustawa z dnia 15 marca 1933 r. o szkołach akademickich, Dz.U. z 1933 r. Nr 29, poz. 247.

Woźniak E., Polityka językowa państwa polskiego w okresie międzywojennym, „Socjolingwistyka” 29, 2015.

Берегсасі А., Черничко С., Державний статус украӥнської/русинської (руської) мови на Закарпатті y XX cmoлimmi, [w:] Teka Komisji Polsko-Ukraińskich Związków Kulturowych, OL PAN, Lublin 2012.

Ганчин В., Деякі історично-правові аспекти мовного питання в Закарпатті, [w:] Українська мова на Закарпатті у минулому і сьогодні. Матеріали науково-практичної конференції (Ужгород, 5-6 травня 1992 року), red. Б. Галас, В. Гадорець, В. Задорожний, Патент, Ужгород 1993.

Марковський В., Міжнародно-правові зобов'язання Другої Речі Посполитої щодо української національної меншини у сфері мовних відносин, „Вісник Львівського університету. Серія юридична” 2013, nr 57.

Черничко С., Фединець Ч., Наш місиевий Вавилон: Історія мовної політики на території сучасного Закарпаття у першій половині ХХ століття (до 1944 року): Монограбія, Поліграфцентр „Ліра”, Ужгород 2014.

Шевельов Ю., Украӥнська мова в першій половині двадиятого століття (1900-1941). Стан і статус, Видавництво „Сучасність”, Київ 1987.

\section{Language policy of Poland and Czechoslovakia concerning the Ukrainian minority in the interwar period (on the example of the schooling of Galicia and Transcarpathia)}

Keywords: the Second Republic of Poland, the Czechoslovakia, national minority, language policy, schooling

\section{Summary}

In the article the international treaties and internal laws and orders of Poland and the Czechoslovakia, which regulate the linguistic rights of national minorities in field of education are studied. Internal legislation of the Czechoslovakia guaranteed free use of minority language both orally and in writing, and provided the right for national minorities to study in their native language in public primary, secondary and higher education. On the contrary, in the constitutional acts of Poland only the right of minorities to study their mother tongue in public primary schools was guaranteed. Due the prevalence of Ukrainians in Galicia, the Polish authorities with respect to these territories performed different national and language policy aimed at deepening regional differences and assimilation of the Ukrainian population. 